\title{
Article \\ Electrochemical and Structural Modifications of Humic Acids in Aerobically and Anaerobically Incubated Peat
}

\author{
Carlo Bravo *(D), Rosanna Toniolo, Marco Contin (D) and Maria De Nobili \\ Department of Agricultural, Food, Environmental and Animal Sciences (DI4A), University of Udine, \\ Via delle Scienze 206, 33100 Udine, Italy; rosanna.toniolo@uniud.it (R.T.); marco.contin@uniud.it (M.C.); \\ maria.denobili@uniud.it (M.D.N.) \\ * Correspondence: carlo.bravo@uniud.it
}

Citation: Bravo, C.; Toniolo, R.;

Contin, M.; Nobili, M.D.

Electrochemical and Structural Modifications of Humic Acids in Aerobically and Anaerobically Incubated Peat. Land 2021, 10, 1189. https://doi.org/10.3390/land10111189

Academic Editor: Daniel S Mendham

Received: 28 September 2021

Accepted: 3 November 2021

Published: 5 November 2021

Publisher's Note: MDPI stays neutral with regard to jurisdictional claims in published maps and institutional affiliations.

Copyright: (c) 2021 by the authors. Licensee MDPI, Basel, Switzerland. This article is an open access article distributed under the terms and conditions of the Creative Commons Attribution (CC BY) license (https:/ / creativecommons.org/licenses/by/ $4.0 /)$.

\begin{abstract}
Exposure to oxygen and aerobic biological activity during drought periods alters the availability of terminal electron acceptors (TEA) in the peat catotelm layer. We investigated the changes in the electrochemical and chemical characteristics of humic acids (HA) induced by subjecting air-dried sphagnum peat to biological oxidation or reduction during a 90-day incubation experiment. Structural modifications of HAs from anaerobically $\left(\mathrm{HA}_{\mathrm{red}}\right)$ and aerobically $\left(\mathrm{HA}_{\mathrm{ox}}\right)$ incubated peat were investigated by ATR-FTIR, UV-vis, and EEM fluorescence spectroscopy. Number and strength of acid groups were characterized by titration, while changes in redox properties were characterized by cyclic voltammetry and quantified by coulometry with mediated electrochemical oxidation (MEO). Exposure to oxygen had small effects, but compared to anaerobic incubation, decreased by $20 \%$ the capacity of HA to reduce the radical ion of 2,2'-Azinobis (3-ethylbenzothiazoline-6-sulfonic acid) $\left(\mathrm{ABTS}^{\bullet-}\right.$ ), passing from $2.77 \pm 0.13 \mathrm{mmol}_{\mathrm{e}-} \mathrm{g}_{\mathrm{HA}}{ }^{-1}$ in $\mathrm{HA}_{\text {red }}$ to $2.21 \pm 0.10 \mathrm{mmol}_{\mathrm{e}-} \mathrm{g}_{\mathrm{HA}}{ }^{-1}$ in $\mathrm{HA}_{\mathrm{ox}}$. Pseudo-first-order electron transfer kinetic constants were $13.3 \pm 1.2 \mathrm{~s}^{-1}$ for $\mathrm{HA}_{\mathrm{ox}}$ and $16.7 \pm 1.4 \mathrm{~s}^{-1}$ for $\mathrm{HA}_{\text {red. }}$ Alterations in the hydrological status of the catotelm have minor effects on the actual in situ availability of organic TEA, but if coupled to intensified biological activity they may result in significant variations of greenhouse gases emissions.
\end{abstract}

Keywords: humic acids; peat; redox changes; electron donating capacity; electron transfer kinetic constants

\section{Introduction}

Peat deposits form because carbon (C) inputs to the catotelm, the anoxic part of the profile, exceed overall $\mathrm{C}$ losses. In fact, in the waterlogged part of the profile, the organic $\mathrm{C}$ (OC) mineralization is hindered by the much lower energy gain allowed by fermentation as compared to aerobic and anaerobic respirations [1,2]. In this way, about 270-370 Pg of C (nearly one-third of the world's soil carbon) were sequestered in peatlands and most of them are accumulated below the permanent level of the water table [3,4]. In the coming decades, as a consequence of global warming, peatlands will be increasingly exposed to drought periods and water table fluctuations are expected to cause the release of huge amounts of greenhouse gases (GHG) [5].

The temperature dependence of the OC decomposition and the effects of shifts in vegetation cover have been extensively investigated and modeled [6,7], but effects of modified oxygen limitations on microbially mediated $\mathrm{C}$ mineralization rates have been underestimated [1]. Moreover, mechanisms underlying $\mathrm{CO}_{2}: \mathrm{CH}_{4}$ emission ratios from peatlands are not fully understood and will contribute to the scarcely known feedback mechanisms that hinder our capability to predict climate change [8,9]. About $10 \%$ of the global natural emissions of methane $\left(54 \mathrm{Tg} \mathrm{y}^{-1}\right)$ originates in bogs and organic horizons of tundra soils [10] and, considering that $\mathrm{CH}_{4}$ has a global warming potential 25 times that of $\mathrm{CO}_{2}$, it is important to understand which factors may be important in affecting emission ratios from peatlands. Among these, the availability of terminal electron acceptors (TEA) that fuel microbial anaerobic respiration is one of the most crucial. 
In natural peatlands, as long as the soil is waterlogged, anaerobic respiration is limited by the completely reduced state of TEA. Conversely, in soils with fluctuating water tables, anaerobic respiration prevails for two to three weeks after re-submergence, because of the renewed availability of oxidized TEA that ensues after drainage and exposure to air [4]. During this stage, more $\mathrm{CO}_{2}$ and less $\mathrm{CH}_{4}$ is released from the upper layers compared to continuously submerged conditions. Keller and Takagi [11] demonstrated that the reduction of organic TEA is coupled to the production of a significant fraction of the $\mathrm{CO}_{2}$ released from a bog soil during anaerobic respiration, whereas $\mathrm{CH}_{4}$ is not produced until the electron-accepting capacity of organic TEA is exhausted. The higher energy yield of anaerobic respiration compared to methanogenesis provides the thermodynamic justification for the higher $\mathrm{CO}_{2}: \mathrm{CH}_{4}$ production ratios observed.

Compared to mineral soils, peatlands are naturally poor in inorganic TEA such as nitrate and $\mathrm{Fe}(\mathrm{III})[8,12]$, so $\mathrm{CO}_{2}: \mathrm{CH}_{4}$ production ratios higher than one can only be sustained by reduction of humic acids (HAs) [13]. In fact, HAs which can act as organic TEA [14] are contained in large amounts in peat [15-17]. Keller et al. [16] proved that the addition of HA alters the ratio of $\mathrm{CO}_{2}: \mathrm{CH}_{4}$ produced during anaerobic laboratory incubations. Moreover, HAs and HA-analogs have been proven to inhibit methane production in different types of peatlands by various mechanisms $[18,19]$.

Redox-active species require activation by fluctuating redox conditions to maintain their capability to serve as TEA: this implies frequent switching between reducing and oxidizing conditions, as can be attained by hydrological perturbations that cause water table fluctuations [20].

The greater incidence and length of drought periods fostered by climate change will cause a more and more frequent onset of aerobic conditions in thicker sections of peat deposit profiles [21,22]. Impacts of water table lowering on GHG emissions from peatlands are highly variable: most studies report reductions in $\mathrm{CH}_{4}$ emissions, although the overall balance foresees a net increase from 0.73 to $0.86 \mathrm{Gt} \mathrm{CO}_{2}$-eq yr ${ }^{-1}$ by the end of the century [23]. The factors that affect the mechanisms underlying this variability have not been fully elucidated yet, but HA certainly play a pivotal role [19]. Besides enforcing aerobic mineralization during low water table periods, it is reasonable to hypothesize that both exposure to oxygen and aerobic biological activity contribute to alter the redox properties of HA increasing the overall availability of TEA and faster anoxic decomposition during the ensuing periods of flooding [24].

Previous studies investigated the effects of the addition of model organic TEA, HAs, and of the biological reduction of solid organic materials on greenhouse gas emissions from peat $[25,26]$, and the redox cycling of solid HAs in suspension by pure bacterial strains $[17,27]$. However, no studies have so far directly addressed the evaluation of changes caused by modifying the conditions of peat on the capability of HA to act as TEA.

We hypothesized that changes in the redox properties of HA in their native solid state, are not only caused by exposure to oxygen but that aerobic biological activity modifies them and contributes to alter the availability of TEA in the catotelm layer.

In this work, we therefore analyzed HA extracted from: (i) a peat sample that had been dried and exposed to air; and (ii) the same peat after it underwent biological oxidation or reduction in mesocosms during a 90-day incubation experiment. Changes in the redox state of HA were quantified with cyclic voltammetry and coulometry by means of mediated electrochemical oxidation (MEO) and structural modifications of biologically reduced $\left(\mathrm{HA}_{\mathrm{red}}\right)$ and oxidized $\left(\mathrm{HA}_{\mathrm{ox}}\right)$ humic acids were investigated by ATR-FTIR, UV-vis, and EEM fluorescence spectroscopy.

\section{Materials and Methods}

\subsection{Chemicals}

Sodium hydroxide, phosphoric acid, potassium persulfate, hydrochloric acid (all puriss. p.a.), 2,2'-Azinobis (3-ethylbenzothiazoline-6-sulfonic acid) $(>98 \%)\left(\mathrm{ABTS}^{2-}\right)$ diammonium salt were obtained from Sigma-Aldrich (St. Louis, MO, USA). All solutions 
were prepared using high purity water (18 $\mathrm{M} \Omega$ resistivity, Milli-Q Corp.), deoxygenated and $\mathrm{N}_{2}$ saturated (purged for $2 \mathrm{~h}$ under continuous stirring).

\subsection{Experiment Layout}

Lithuanian sphagnum peat $(\mathrm{pH}=3.7$, Von Post index $\mathrm{H}=4$ ) that had been stored air-dried in a perforated plastic bag for more than a year, was sieved at $2 \mathrm{~mm}$, homogenized, and incubated in mesocosms under either fully aerobic or anaerobic conditions (Figure 1). Aerobic ( $40 \%$ of water holding capacity (WHC), continuous insufflation of air) and anaerobic (submerged under water previously purged with $\mathrm{N}_{2}$ for $2 \mathrm{~h}$ and kept under $\mathrm{N}_{2}$ atmosphere) mesocosms were incubated, in triplicate, in the dark in a thermostatic cell at $25^{\circ} \mathrm{C}$ for 90 days. Each mesocosm contained an amount of peat corresponding to $200 \mathrm{~g}$ dry weight, which had been thoroughly mixed just before incubation with $3 \mathrm{~g}$ of ground poplar litter to boost biological activity [28,29], and $1 \mathrm{~g}$ of an aerobic or anaerobic fresh soil as natural inoculum. In the case of the anaerobic treatment, all operations (including HA extraction) were carried out inside an anoxic glove box $\left(\mathrm{N}_{2}\right.$ saturated; $\left.\mathrm{O}_{2}<0.1 \mathrm{ppm}\right)$.

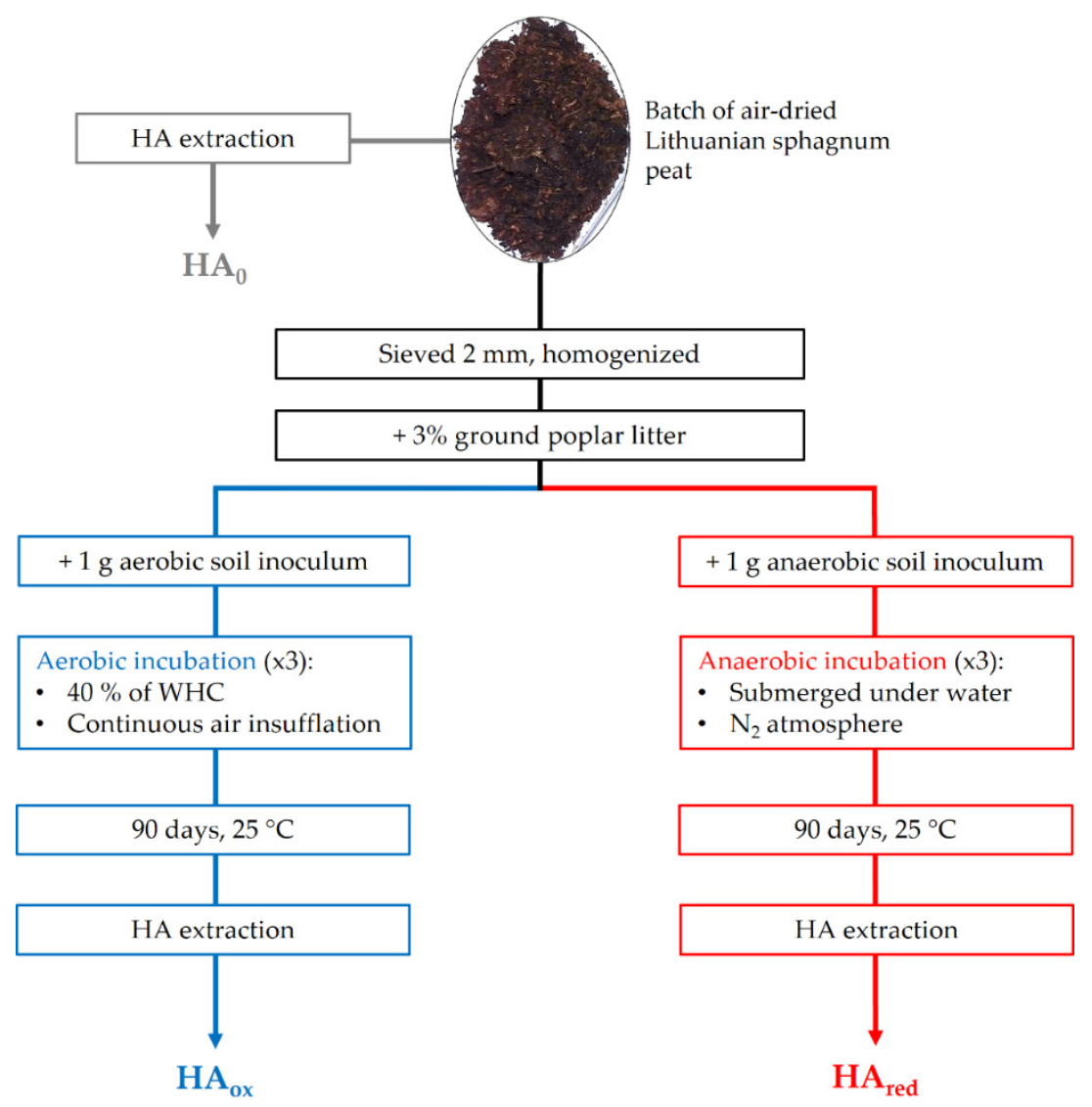

Figure 1. Schematic representation of the experimental layout.

\subsection{HA Extraction}

Humic acids were extracted from the air-dried peat $\left(\mathrm{HA}_{0}\right)$ and from the aerobically $\left(\mathrm{HA}_{\mathrm{ox}}\right)$ and anaerobically $\left(\mathrm{HA}_{\text {red }}\right)$ incubated peat following the procedure recommended by the IHSS. Briefly, extractions were carried out using $0.1 \mathrm{M} \mathrm{NaOH}$ for $4 \mathrm{~h}$ at 1:20 peat/solution ratio. Suspensions were centrifuged (14,000 rpm for $30 \mathrm{~min})$ and supernatants were filtered through $0.2 \mu \mathrm{m}$ cellulose filters and acidified to $\mathrm{pH} 1$ using $6 \mathrm{M} \mathrm{HCl}$ to allow HA precipitation. After washing twice with Milli-Q water, HA were frozen and then freeze-dried. The ash content, determined gravimetrically after burning $50 \mathrm{mg}$ of each isolated HA in a muffle furnace at $500{ }^{\circ} \mathrm{C}$ for $4 \mathrm{~h}$, was less than $2 \%$ in all samples. HA stock solutions were prepared by dissolving a certain amount of HA in $0.1 \mathrm{M}$ anoxic phosphate buffer ( $\mathrm{pH} 7.0)$. 


\subsection{HA Characterization}

Organic carbon $(\mathrm{OC})$ and total nitrogen $\left(\mathrm{N}_{\text {tot }}\right)$ contents, and carbon stable isotope composition $\left(\delta^{13} \mathrm{C}\right)$ of the original peat and extracted HA were determined with a $\mathrm{CHN}$ elemental analyzer (Vario Microcube, Elementar) coupled with a stable isotope ratio mass spectrometer (Isoprime 100, Elementar). Caffeine IAEA was used as international reference material.

Titration of acidic groups was carried out under $\mathrm{N}_{2}$ with a Mettler Memo titrator DL 50, according to [30].

UV-vis spectra of HA were recorded using a Cary Varian Spectrophotometer in $1 \mathrm{~cm}$ quartz cuvettes over a wavelength interval from 220 to $800 \mathrm{~nm}$ at a scan rate of $60 \mathrm{~nm} \mathrm{~min}{ }^{-1}$. Each spectrum was normalized by the OC concentration of the sample.

Fluorescence emission-excitation matrices (EEMs) of HA solutions $\left(15 \mathrm{mg} \mathrm{L}^{-1}\right)$ were collected on a Cary Eclipse fluorescence spectrophotometer (Agilent Technologies) at varying excitation wavelengths from 230 to $500 \mathrm{~nm}$ ( $5 \mathrm{~nm}$ steps). Emission was recorded from 350 to $550 \mathrm{~nm}\left(1 \mathrm{~nm}\right.$ steps, scan rate $\left.600 \mathrm{~nm} \mathrm{~min}^{-1}\right)$. Solutions were thermostated at $20.0 \pm 0.5^{\circ} \mathrm{C}$. EEMs were blank subtracted and fluorescence intensities (F.I.) normalized for the OC concentration.

FTIR spectra were recorded with an FT-IR Spectrum 100 (PerkinElmer) spectrometer equipped with a universal ATR (attenuated total reflectance) sampling device containing a diamond/ZnSe crystal. The spectra were recorded at room temperature in transmission mode over a wavenumber interval from 4000 to $500 \mathrm{~cm}^{-1}$ (64 scans). A background spectrum of air was scanned under the same instrumental conditions before each series of measurements. Intensity ratios (R) were calculated for specific pairs of bands [31].

\subsection{Electrochemical Measurements}

Cyclic voltammograms (CV) were recorded by a 430A CHI electrochemical analyzer in $0.1 \mathrm{M}$ anoxic phosphate buffer ( $\mathrm{pH} 7.0$ ) solutions (10-12 mL), under anoxic atmosphere, using a $3 \mathrm{~mm}$ diameter glassy carbon (GC) disk working electrode (WE), an $\mathrm{Ag} / \mathrm{AgCl}$ reference electrode and a $\mathrm{Pt}$ wire auxiliary electrode. The WE was cleaned after each CV using 1.0 and $0.05 \mu \mathrm{m}$ aluminum oxide on polishing pads, thoroughly rinsed with Milli-Q water, and dried. The cathodic and anodic vertex potentials were fixed at $E_{\mathrm{h}}=+0.15 \mathrm{~V}$ and $+0.95 \mathrm{~V}$ (scan rate $v=0.010 \mathrm{~V} \mathrm{~s}^{-1}$ ). CVs were collected in the presence of only HA $\left(0.2-2.0 \mathrm{~g} \mathrm{~L}^{-1}\right)$ and in the presence of both $\mathrm{ABTS}^{2-}(3$ or $60 \mu \mathrm{M})$ and HA $(0.05$ to $\left.3.5 \mathrm{~g} \mathrm{~L}^{-1}\right)$ [32].

Mediated electrochemical oxidation (MEO) measurements were carried out, under anoxic atmosphere and continuous solution stirring, in a bulk electrolysis cell containing a macro GC WE polarized to $E_{\mathrm{h}}=+0.606 \mathrm{~V}$, an $\mathrm{Ag} / \mathrm{AgCl}$ reference electrode and a $\mathrm{Pt}$ wire auxiliary electrode (separated by a porous glass frit). $\mathrm{ABTS}^{2-}$ was used as electrochemical mediator to shuttle electrons from electron-donating moieties in HA to the WE [33]. After oxidation of a $0.20 \mathrm{mM} \mathrm{ABTS}^{2-}$ solution $(0.1 \mathrm{M}$ phosphate buffer, $\mathrm{pH} 7)$, small aliquots of HA were spiked into the electrochemical cell. Oxidative currents were automatically integrated by a digital current integrator (Model 731, Amel) to quantify the electron donating capacity (EDC) of HA. In CVs and MEO potentials were measured vs. $\mathrm{Ag} / \mathrm{AgCl}$ but are reported vs. standard hydrogen electrode (SHE).

\subsection{Statistics}

Incubations were performed in triplicate, all electrochemical measurements were analytically replicated at least three times, while other analyses were performed in duplicate and reported in tables and figures as mean \pm standard error (SE). Differences between treatments were tested by Tukey's HSD and considered significant at $p<0.05$. Regression analysis, test of significance of the correlation coefficient, and analysis of parallelism were carried out by $\mathrm{R}$ software [34,35]. 


\section{Results}

\subsection{HA Composition}

$\mathrm{OC}, \mathrm{N}_{\text {tot }}$ and $\delta^{13} \mathrm{C}$ values of the original peat sample and of $\mathrm{HA}_{0}, \mathrm{HA}_{\mathrm{ox}}$ and $\mathrm{HA}_{\text {red }}$ are reported in Table 1 . The results show that neither addition of poplar litter and soil inoculum nor incubation altered the $\mathrm{C}$ and $\mathrm{N}$ content and isotopic composition of HA, albeit a slight decrease in $\mathrm{C} / \mathrm{N}$ ratio was observed in $\mathrm{HA}_{\mathrm{ox}}$ as could be reasonably expected in an aerobic process.

Table 1. Organic carbon $(\mathrm{OC})$, total nitrogen $\left(\mathrm{N}_{\text {tot }}\right)$, and carbon stable isotope composition $\left(\delta^{13} \mathrm{C}\right)$ of the original peat sample and of $\mathrm{HA}$ extracted before $\left(\mathrm{HA}_{0}\right)$ and after aerobic $\left(\mathrm{HA}_{\mathrm{ox}}\right)$ and anaerobic $\left(\mathrm{HA}_{\text {red }}\right)$ incubations. Different letters $(\mathrm{a}, \mathrm{b}, \mathrm{c})$ refer to significant differences (HSD test, $\left.p<0.05\right)$. All data are expressed on a dry weight basis.

\begin{tabular}{|c|c|c|c|c|}
\hline & OC (\%) & $\mathrm{N}_{\text {tot }}(\%)$ & $\mathbf{C} / \mathbf{N}$ & $\left.\delta^{13} \mathrm{C}(\%)\right)^{1}$ \\
\hline Original Peat & $45.9 \pm 1.0^{\mathrm{a}}$ & $1.10 \pm 0.06^{\mathrm{a}}$ & $41.7^{\mathrm{a}}$ & $-27.04 \pm 0.05^{a}$ \\
\hline $\mathrm{HA}_{0}$ & $48.8 \pm 0.2^{b}$ & $1.96 \pm 0.20^{b}$ & $24.9^{b}$ & $-26.98 \pm 0.04^{a}$ \\
\hline $\mathrm{HA}_{\mathrm{ox}}$ & $48.8 \pm 0.5^{b}$ & $2.22 \pm 0.12^{b}$ & $22.0^{\mathrm{C}}$ & $-27.08 \pm 0.02^{a}$ \\
\hline $\mathrm{HA}_{\text {red }}$ & $48.9 \pm 0.2^{b}$ & $1.93 \pm 0.14^{b}$ & $25.3^{b}$ & $-26.97 \pm 0.04^{a}$ \\
\hline
\end{tabular}

\subsection{Electrochemical Behavior of $H A s$}

At potentials above $+0.5 \mathrm{~V}$, the CVs of both $\mathrm{HA}_{\mathrm{ox}}$ and $\mathrm{HA}_{\text {red }}$ (Figure $2 \mathrm{a}, \mathrm{b}$ ) displayed more intense oxidative currents during anodic scanning demonstrating not only that HAs can directly transfer electrons to the GC WE and that the intensity of the anodic current is linearly proportional to the concentration of $\mathrm{HA}$, but also that more electrons were exchanged by $\mathrm{HA}_{\text {red }}$. Electrode passivation by surface-active fractions of $\mathrm{HA}$ probably occurred at relatively higher concentrations of HAs, as indicated by the lower reproducibility of scans when the concentration of HAs in the electrochemical cell exceeded $1.0 \mathrm{~g} \mathrm{~L}^{-1}$.
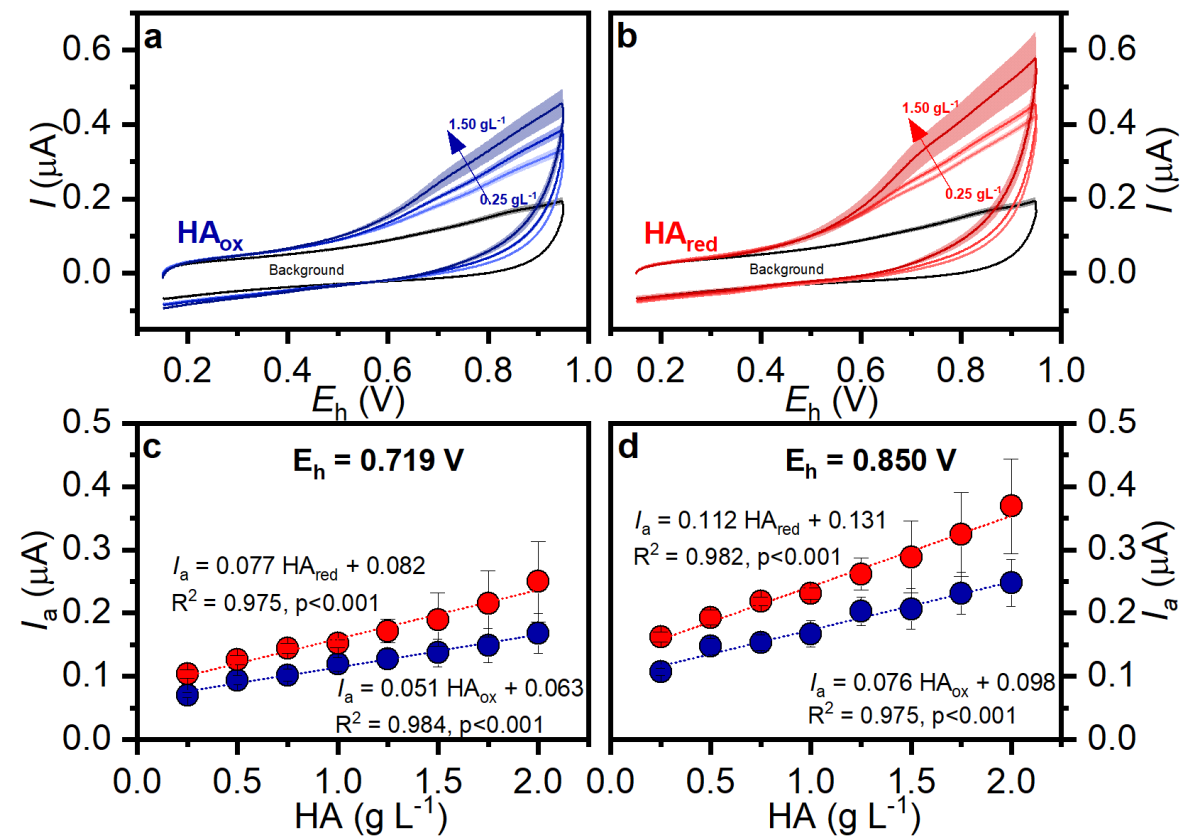

Figure 2. Cyclic voltammograms (CVs) of solutions $\left(0.25,0.50\right.$, and $\left.1.50 \mathrm{~g} \mathrm{~L}^{-1}\right)$ of $\mathrm{HA}_{\mathrm{ox}}(\mathbf{a})$ and $\mathrm{HA}_{\text {red }}(\mathbf{b})$. Black traces represent the $\mathrm{CV}$ of the background electrolyte. Diagrams below report linear correlations between anodic currents at $0.719 \mathrm{~V}(\mathbf{c})$ and $0.850 \mathrm{~V}(\mathbf{d})$ versus $\mathrm{HA}_{\mathrm{ox}}$ (blue symbols) and $\mathrm{HA}_{\text {red }}$ (red symbols) concentrations. 
Linear correlations were found between HA concentrations and anodic current intensities $\left(I_{\mathrm{a}}\right)$ measured at $0.850 \mathrm{~V}$, a potential at which most redox active groups of HA can be presumed to be oxidized (Figure $2 \mathrm{~d}$ ). $\mathrm{HA}_{\text {red }}$ presented significantly steeper slope $(p<0.005)$ compared to $\mathrm{HA}_{\mathrm{ox}}$. Therefore, the direct transfer of electrons to the WE by a unit mass of HAs (slope of the regression line) decreased by about $50 \%$ after by exposure of peat to the activity of aerobic microorganisms. Because of the sluggish response, however, a proper quantitation of electron exchange by HA cannot be performed by direct electrochemical oxidation.

The featureless CVs of HAs (Figure 2) not only suggested the lack of defined oxidation or reduction potentials for both $\mathrm{HA}_{\text {red }}$ and $\mathrm{HA}_{\mathrm{ox}}$, but also a sluggish electron transfer to the WE, which was later confirmed by the fact that no defined end point was reached even by $\mathrm{ABTS}^{2-}$ mediated coulometric MEO. Therefore, after checking the linearity of the oxidative peak currents of both HAs at $0.719 \mathrm{~V}$, the potential corresponding to that of the anodic peak of $\mathrm{ABTS}^{2-}$ (Figure 2c), quantitative measurements were carried out by MEO with in $\mathrm{ABTS}^{2-}$ solutions.

\subsection{Electron Transfer Kinetic Constants from CV}

To further characterize the electrochemical behavior of microbially reduced and oxidized HAs with quantitative measurements and to calculate pseudo first order kinetic constants of electron transfer, we used $\mathrm{ABTS}^{2-}$ to mediate the electron transfer from electron donating moieties in HAs to the WE. The CV of $\mathrm{ABTS}^{2-}$ solutions showed a reversible charge transfer process and obeyed the Randles-Sevcik law as confirmed by the linear correlations found between the oxidative peak current $\left(I_{p, a}\right)$ and its concentration $\left(\mathrm{R}^{2}=1.00\right)$ and $v^{1 / 2}\left(\mathrm{R}^{2}=1.00\right)$ (data not shown).

The catalytic currents registered in the presence of both $\mathrm{ABTS}^{2-}$ and HA were much higher than when only one component was present in the solution and increased with the HA concentration (Figure 3). This reflects the fact that at the boundary layer ABTS ${ }^{2-}$ was oxidized to $\mathrm{ABTS}^{\bullet-}\left(\mathrm{ABTS}^{2-} \rightleftarrows \mathrm{ABTS}^{\bullet-}+1 \mathrm{e}^{-}\right.$, heterogeneous oxidation step at the WE surface), but the radical ion was then chemically reduced back by HA (ABTS ${ }^{\bullet-}+\mathrm{HA} \rightarrow$ $\mathrm{ABTS}^{2-}+\mathrm{HA}^{\bullet}$, homogeneous reduction step) regenerating the non-radical reduced form $\left(\mathrm{ABTS}^{2-}\right)$, which can once again be oxidized at the WE.

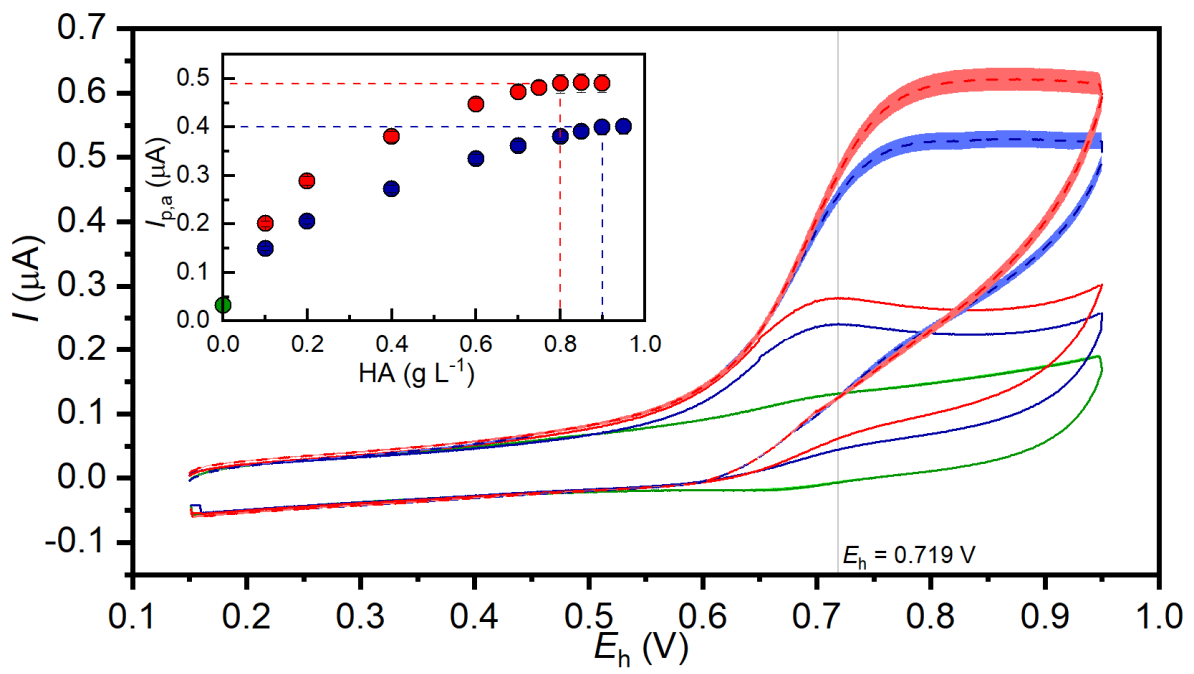

Figure 3. Cyclic voltammograms ( $\mathrm{CVs}$ ) of solutions containing only $3 \mu \mathrm{M} 2,2^{\prime}$-azino-bis (3-ethylbenzothiazoline-sulfonate) $\left(\mathrm{ABTS}^{2-}\right.$, green trace) and $\mathrm{ABTS}^{2-}$ plus varying amounts of $\mathrm{HA}_{\mathrm{ox}}\left(0.1\right.$ and $0.9 \mathrm{~g} \mathrm{~L}^{-1}$, blue traces) and $\mathrm{HA}_{\text {red }}\left(0.1\right.$ and $0.8 \mathrm{~g} \mathrm{~L}^{-1}$, red traces). Inset: anodic peak currents $\left(I_{p, a}\right)$ versus HA concentrations. The dashed lines indicate the limit currents $\left(I_{\text {lim }}\right)$ and the corresponding limiting concentrations. 
At increasing concentrations of HA, in the presence of $3 \mu \mathrm{M} \mathrm{ABTS}^{2-}$, the catalytic anodic peak currents increased linearly with the concentration of HAs up to $0.5 \mathrm{~g} \mathrm{~L}^{-1}$. Then, at $0.8 \mathrm{~g} \mathrm{~L}^{-1}$ for $\mathrm{HA}_{\text {red }}$ and $0.9 \mathrm{~g} \mathrm{~L}^{-1}$ for $\mathrm{HA}_{\mathrm{ox}}$ stationary state conditions were reached, at which the voltammetric response was no longer a peak but assumed a sigmoidal shape and no backward peak was found. At this stage, the homogeneous regeneration reaction (i.e., $\mathrm{ABTS}^{\bullet}-$ reduction by HA) occurred quantitatively during the potential sweep. From the intensity of the plateau currents $\left(I_{\text {lim }}\right)$ it is possible to calculate pseudo-first-order kinetic constants $\left(k_{f}^{\prime}\right)$ of the electron transfer between $\mathrm{ABTS}^{\bullet-}$ and $\mathrm{HA}_{\mathrm{ox}}$ or $\mathrm{HA}_{\text {red }}$, as suggested by [36]

$$
k_{f}^{\prime}=\left(0.4463 I_{\text {lim }} / I_{d}\right)^{2} \mathrm{Fv} / R T
$$

where $I_{d}$ is the peak current when only ABTS ${ }^{2-}$ is present in solution, $F$ is Faraday's constant $\left(96,487 \mathrm{C} \mathrm{mol}^{-1}\right), v$ is the scan rate $\left(0.010 \mathrm{~V} \mathrm{~s}^{-1}\right), R$ is the ideal gas constant $(8.31 \mathrm{~J}), T$ is the absolute temperature $(298 \mathrm{~K})$. The calculated $k_{f}^{\prime}$ values were $13.3 \pm 1.2$ and $16.7 \pm 1.4 \mathrm{~s}^{-1}$ for $\mathrm{HA}_{\mathrm{ox}}$ and $\mathrm{HA}_{\text {red }}$, respectively. This indicated that, compared to $\mathrm{HA}_{\mathrm{ox}}$, $\mathrm{HA}_{\text {red }}$ can donate electrons faster $(\sim 30 \%)$ to the $\mathrm{ABTS}^{\bullet-}$ radical.

\subsection{Quantification of Redox Changes}

The effects of the aerobic/anaerobic incubation on the redox state of HA were quantified by MEO (Figure 4). The amount of excess charge transferred to the electrode by $\mathrm{ABTS}^{\bullet-}$ in the presence of HAs is directly proportional to the number of electrons, $n_{e^{-}}(\mathrm{mol})$, transferred from HAs to the radical $\mathrm{ABTS}^{\bullet-}$

$$
n_{\mathrm{e}-}=Q / F
$$

where $Q$ is the integrated charge $(C)$ and $F$ is the Faraday constant. The $\mathrm{EDC}\left(\mathrm{mmol}_{\mathrm{e}}-\mathrm{g}_{\mathrm{HA}}{ }^{-1}\right)$ of $\mathrm{HA}_{\mathrm{ox}}$ and $\mathrm{HA}_{\text {red }}$ were calculated after $60 \mathrm{~min}$ from $\mathrm{HA}$ addition, by normalizing $n_{e-}$ to the mass of the sample.

The EDC of $\mathrm{HA}_{\mathrm{ox}}\left(2.21 \pm 0.10 \mathrm{mmol}_{\mathrm{e}} \mathrm{g}_{\mathrm{HA}}{ }^{-1}\right)$ was $\sim 20 \%$ lower $(p<0.05)$ than that of $\mathrm{HA}_{\text {red }}\left(2.77 \pm 0.13 \mathrm{mmol}_{\mathrm{e}-} \mathrm{g}_{\mathrm{HA}}{ }^{-1}\right)$. This shows that peat incubation under oxic conditions resulted in a significant decrease in the reduced redox active moieties on HA molecules. The EDC value of the HA extracted from the original peat sample, which had been excavated and exposed to oxygen during and after drying, was $2.48 \pm 0.18 \mathrm{mmol}_{\mathrm{e}-} \mathrm{g}_{\mathrm{HA}}{ }^{-1}$ : oxidation in the absence of biological activity apparently diminished the EDC of HA by less than $10 \%$ (data not shown).

\subsection{Structural Changes}

Spectral parameters calculated from UV-vis spectra revealed that HA underwent structural changes. All UV-vis spectra showed a monotonical decrease of the specific absorbance (SA) with increasing wavelengths and a shoulder around 260-280 $\mathrm{nm}$ (conjugation of quinones and ketones [37]) (Figure S1). However, lower specific absorption was displayed by $\mathrm{HA}_{\text {red }}$ at high wavelengths $(>400 \mathrm{~nm})$. This can be associated to the decrease of charge transfer contacts, brought about by the reduction of electron acceptor groups that triggers a decrease of the electron delocalization in aromatic structures [38]. On the other side, aromaticity itself was not affected, as SUVA 254 values of $\mathrm{HA}_{\mathrm{ox}}\left(4.77 \pm 0.12 \mathrm{~L} \mathrm{mg}^{-1} \mathrm{~cm}^{-1}\right)$ and $\mathrm{HA}_{\text {red }}\left(4.66 \pm 0.16 \mathrm{~L} \mathrm{mg}^{-1} \mathrm{~cm}^{-1}\right)$ did not display significant differences $(p>0.40)$ (Table 2). A bathochromic shift of UV absorption (at $254 \mathrm{~nm}$ ) towards higher $(5 \mathrm{~nm})$ wavelengths was displayed by $\mathrm{HA}_{\mathrm{ox}}$. This shift is compatible with the oxidation of hydroquinone groups during aerobic incubation. The $\mathrm{E}_{4} / \mathrm{E}_{6}$ ratio of $\mathrm{HA}_{\mathrm{ox}}(5.83 \pm 0.05)$ was significantly higher than $\mathrm{HA}_{\text {red }}(5.52 \pm 0.04, p<0.05)$ confirming that some oxidative depolymerization probably occurred during aerobic incubation as also shown by the decrease in $\mathrm{C} / \mathrm{N}$ ratio (Table 2) [39]. 


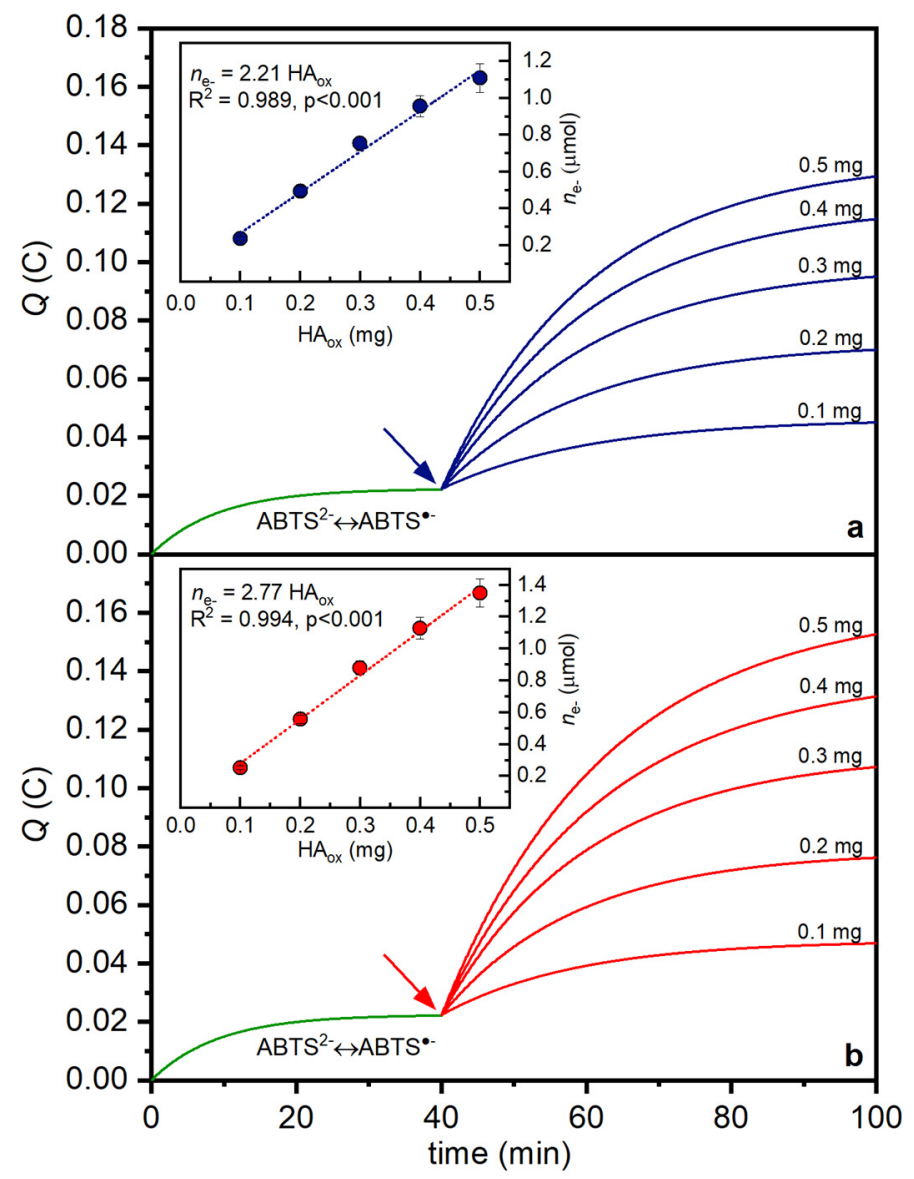

Figure 4. Oxidative charge responses to spikes of increasing $\mathrm{HA}_{\mathrm{ox}}(\mathbf{a})$ and $\mathrm{HA}_{\text {red }}(\mathbf{b})$ masses, added in the electrochemical cell containing $\mathrm{ABTS}^{2-} / \mathrm{ABTS}^{\bullet-}$ in equilibrium to the working electrode $\left(\mathrm{E}_{\mathrm{h}}=0.606 \mathrm{~V}, \mathrm{pH} 7\right)$. Insets: Linear correlation between the moles of electrons $\left(n_{e_{-}}\right)$transferred to the WE versus the mass of $\mathrm{HA}_{\mathrm{ox}}(\mathbf{a})$ and $\mathrm{HA}_{\text {red }}(\mathbf{b})$ after $60 \mathrm{~min}$ from addition. The slopes of the linear regression models correspond to the EDC values.

Table 2. Spectroscopic parameters of humic acids extracted after aerobic $\left(\mathrm{HA}_{\mathrm{ox}}\right)$ and anaerobic $\left(\mathrm{HA}_{\text {red }}\right)$ incubations. Different letters $(a, b)$ refer to significant differences (HSD test, $p<0.05)$. All data are expressed on a dry weight basis.

\begin{tabular}{|c|c|c|c|c|c|c|c|}
\hline & \multirow{2}{*}{$\begin{array}{c}{ }^{1} \text { SUVA }_{254} \\
\left(\mathrm{mg}^{-1} \mathrm{~cm}^{-1}\right)\end{array}$} & \multirow{2}{*}{${ }^{1} \mathrm{E}_{4} / \mathrm{E}_{6}$} & \multirow{2}{*}{$\begin{array}{c}{ }^{1} \mathrm{SA}_{400} \\
\left(1 \mathrm{mg}^{-1} \mathrm{~cm}^{-1}\right)\end{array}$} & \multicolumn{2}{|c|}{${ }^{2}$ Peak A } & \multicolumn{2}{|c|}{${ }^{2}$ Peak B } \\
\hline & & & & Ex/Em & F.I. & Ex/Em & F.I. \\
\hline $\mathrm{HA}_{\text {red }}$ & $4.66 \pm 0.16^{\mathrm{a}}$ & $5.52 \pm 0.04^{a}$ & $0.98^{\mathrm{a}}$ & $255 / 470$ & $0.71^{\mathrm{a}}$ & $340 / 470$ & $0.58^{a}$ \\
\hline $\mathrm{HA}_{\mathrm{ox}}$ & $4.77 \pm 0.12^{\mathrm{a}}$ & $5.83 \pm 0.05^{b}$ & $1.14^{\mathrm{b}}$ & $260 / 470$ & $0.65^{\mathrm{a}}$ & $340 / 470$ & $0.53^{a}$ \\
\hline
\end{tabular}

${ }^{1}$ from UV-vis. ${ }^{2}$ from EEM fluorescence.

Fluorescence EEM (Figure S2 and Table 2) of HA were little affected by the aerobic/anaerobic incubations and showed two peaks at excitation/emission wavelengths of 250/475 and 330/475 nm.

ATR-FTIR spectra of $\mathrm{HA}_{\mathrm{ox}}$ and $\mathrm{HA}_{\text {red }}$ (Figure 5) displayed typical peat HA absorption bands and exhibited broad $\mathrm{OH}$ stretching absorption in around $3300 \mathrm{~cm}^{-1}$, broadened by intermolecular hydrogen bonding and/or $\mathrm{H}$-bonded $\mathrm{OH}$ attributed to phenolic groups and similar weak absorption bands associated with aliphatic $\mathrm{C}-\mathrm{H}$. The band due to $\mathrm{C}=\mathrm{O}$ stretching in carboxyls $\left(1720 \mathrm{~cm}^{-1}\right)$ overlapped with the band at $1650 \mathrm{~cm}^{-1}$ generally attributed to aromatic $\mathrm{C}=\mathrm{C}, \mathrm{C}=\mathrm{O}$, and/or $\mathrm{C}=\mathrm{O}$ of conjugated ketones or to $\mathrm{C}=\mathrm{N}$ amide $\mathrm{I}$ stretching. Absorption at $1600 \mathrm{~cm}^{-1}$ is related to aromatic skeleton vibrations. Other relevant bands were: a discrete peak at about $1515 \mathrm{~cm}^{-1}$ (uncondensed aromatic compounds bound to $\mathrm{N}$ and $\mathrm{O}$ atoms); two small peaks at 1450 and $1420 \mathrm{~cm}^{-1}\left(\mathrm{C}-\mathrm{H}\right.$ bending of $\mathrm{CH}_{2}$ 
and $\mathrm{CH}_{3}$ groups); a band at $1215 \mathrm{~cm}^{-1}$ (stretching $\mathrm{C}-\mathrm{O}$ and bending $\mathrm{O}-\mathrm{H}$ vibrations) and stretching of carbohydrate or alcoholic $\mathrm{C}-\mathrm{O}$ at $1030 \mathrm{~cm}^{-1}$.

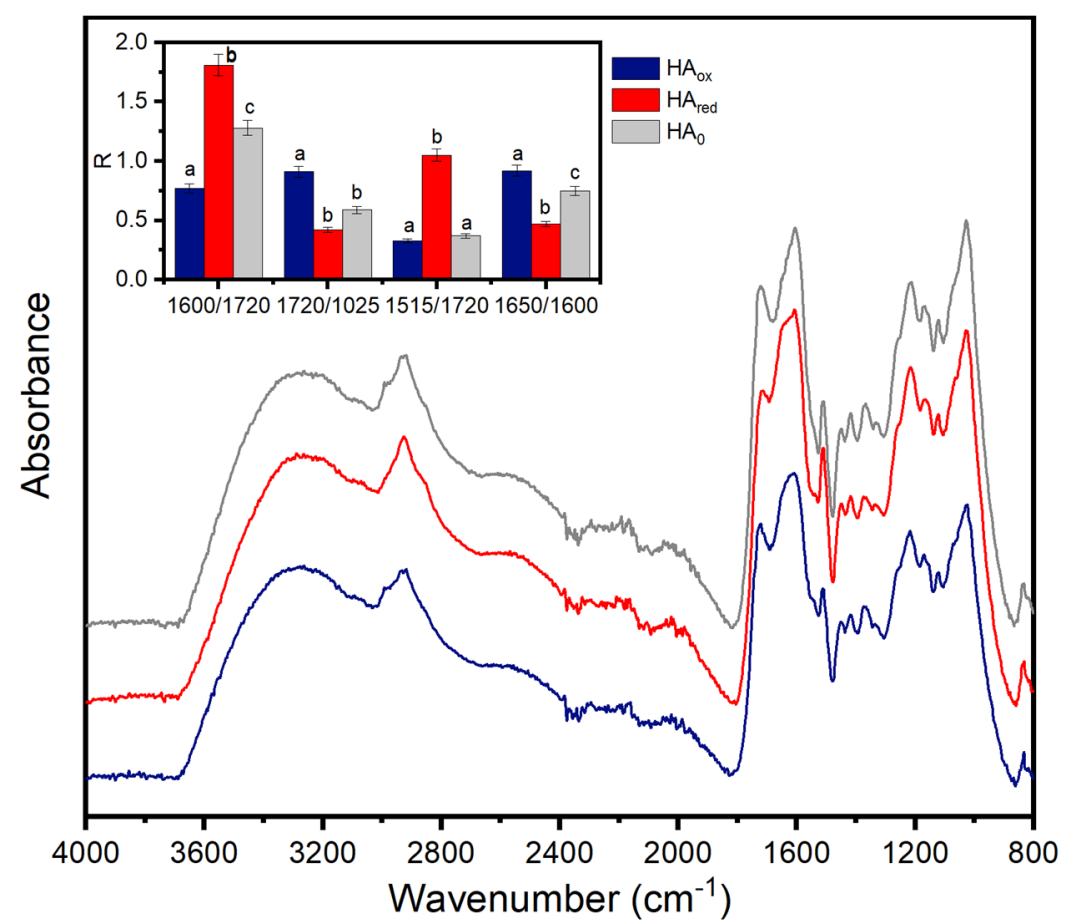

Figure 5. ATR-FTIR spectra of $\mathrm{HA}_{\mathrm{ox}}$ (blue), $\mathrm{HA}_{\text {red }}$ (red) $\mathrm{HA}_{0}$ (grey). Inset: relative intensity ratios (R) of selected bands. Different letters refer to significant differences (HSD test, $p<0.05$ ).

Changes were highlighted by calculating the relative intensity ratios of selected bands (Figure 5, inset). The $1720 / 1025 \mathrm{~cm}^{-1}$ intensity ratio, related to variations in sorption by $\mathrm{C}=\mathrm{O}$ stretching in $\mathrm{COOH}$ with respect to $\mathrm{C}-\mathrm{O}$ stretching of carbohydrates and the $1650 / 1600 \mathrm{~cm}^{-1}$ intensity ratio, related to the presence of quinones in aromatic structures were lower in $\mathrm{HA}_{\text {red }}$, whereas ratios calculated with respect to $\mathrm{C}=\mathrm{O}$ stretching in $\mathrm{COOH}$ increased.

A direct titration of HAs was performed to quantify changes in the number of strong and weak acid groups: $\mathrm{HA}_{\mathrm{ox}}$ and $\mathrm{HA}_{\mathrm{red}}$ respectively contained 10.9 and $7.9 \mathrm{mmol} \mathrm{COOH} \mathrm{g} \mathrm{HA}-\mathrm{C}^{-1}$, and 3.6 and $5.4 \mathrm{mmol}$ (phenolic $\mathrm{OH}$ ) $\mathrm{g}_{\mathrm{HA}-\mathrm{C}^{-1}}$. Therefore, the overall number of carboxyl groups decreased in HA after anaerobic incubation, as shown by ATR-FTIR spectra: a likely result of direct or shuttle mediated biological reduction or decarboxylation, whereas that of phenolic groups increased.

Henderson-Hasselbalch elaboration of titration data (Figure 6) also allows determining average $\mathrm{pKa}$ at $\alpha=0.5$ : $\mathrm{HA}_{\text {red }}$ displayed an average $\mathrm{pKa}$ of 5.70. Carboxyl groups of $\mathrm{HA}_{\text {red }}$ were therefore weaker than most aliphatic acids, coherently with the fact that reduction of electron active groups weakens the ionization of carboxyl groups by diminishing their electron withdrawing power.

On the contrary, acid groups of $\mathrm{HA}_{\mathrm{ox}}$ were not only more abundant, but also stronger and typical of substituted aromatic acids, which could form from oxidation of side chains of phenols during aerobic incubations. 


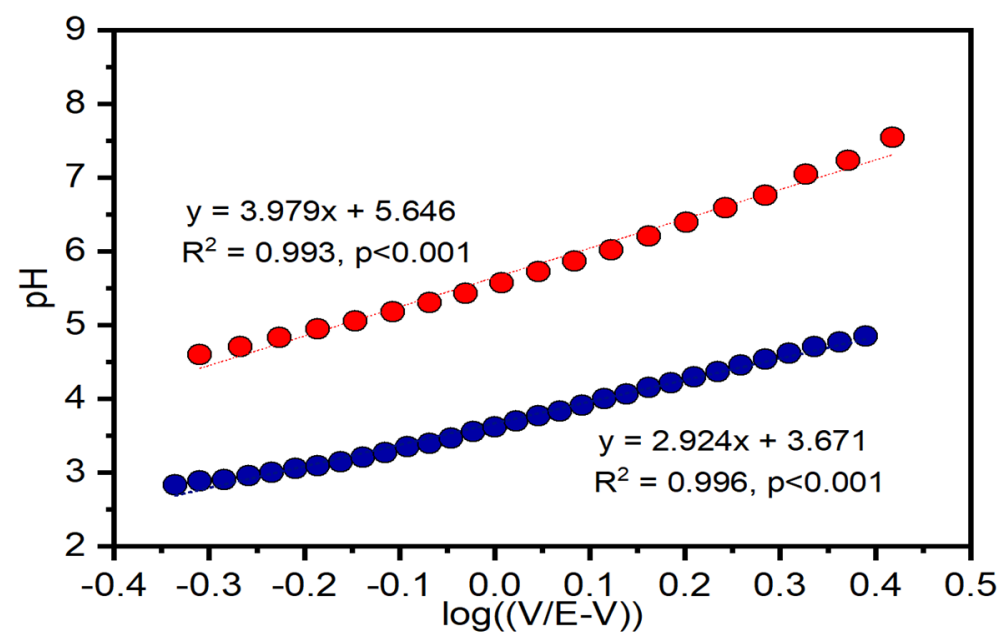

Figure 6. Henderson-Hasselbalch plots of HA extracted from aerobically ( $\mathrm{HA}_{\mathrm{ox}}$, blue circles) and anaerobically $\left(\mathrm{HA}_{\mathrm{red}}\right.$, red circles) incubated peat.

\section{Discussion}

Even if the examined peat was subjected to oxidation during excavation and further during drying and storage, a substantial EDC persisted also in HA extracted from the original peat sample $\left(\mathrm{HA}_{0}\right)$. This shows that exposure to oxygen alone was not sufficient to completely oxidize $\mathrm{HA}$. The residual reduced moieties remained in $\mathrm{HA}_{0}$ may be sterically protected and, therefore, be less reactive and more easily preserved in oxic environments. This protection may be structural or caused by rearrangements that occur during drying [40].

Further oxidation driven by biological activity (under conditions that strongly accelerate biological oxidative processes) did not cause exhaustion of the EDC capacity of $\mathrm{HA}$, but significantly decreased it. Moreover, the lower capability of $\mathrm{HA}_{\mathrm{ox}}$ to transfer electrons is also reflected by their lower pseudo-first-order kinetic constant $\left(k_{f}^{\prime}\right)$ compared to $\mathrm{HA}_{\text {red }}$. This indicates not only that $\mathrm{HA}_{\mathrm{ox}}$ have been further oxidized in their native state by biological processes during the incubation, but also that they possess a lower density of electron donating groups which are less prone to exchange electrons.

The absence of any clearly defined peak in the CV scans of HAs confirmed that electron exchange involves an extensive range of active redox moieties [41]. These likely consist of closely related functional groups, whose reactivity is influenced by differences in their structural environment, resulting in a wide distribution of overlapping redox potentials [42].

Spectral differences (i.e., lower specific absorption was displayed by $\mathrm{HA}_{\text {red }}$ at wavelengths $>400 \mathrm{~nm}$; Table 2) showed a decrease of charge transfer contacts, brought about by the reduction of electron acceptor groups that triggers a decrease of the electron delocalization in aromatic structures [38]. Fluorescence intensities were very low and not significantly different between the samples (Table 2). These results are coherent with those reported by Maurer et al. [43], where electrochemical reduction of soil HAs did not change the EEM peaks position and intensities, and support the doubts about the usefulness of fluorescence measurements in determining the redox states of natural organic matter [44,45].

These results show that drought periods lasting 90 days or less will therefore not cause the complete oxidation of HA. However, they may bring about large alterations of the overall availability of TEA during the subsequent flooding, allowing anaerobic respiration to proceed for longer periods. We must consider, in fact, that HAs are present in peat in large amounts, increasing with depth from $10 \%$ to $30 \%$ in ombrotrophic peat bogs [46] and up to $40 \%$ in low mires [47]. A $20 \%$ decrease in their reduction state is therefore likely to provide, during subsequent submergence periods, enough oxidized redox active moieties to sustain the faster decomposition fueled by anaerobic respiration for much longer periods. These results have important implications. They suggest in fact, that lowering of the water 
table will increase $\mathrm{CO}_{2}$ emission rates from peatlands and might further compromise their carbon balance. All this is coherent with the enhancement in GHG emissions, only partly offset by inhibition of methanogenesis, that was recently predicted through a machine learning upscaling approach by Huang et al. [23].

\section{Conclusions}

This experiment demonstrated that dried peat HAs are further oxidized or reduced when exposed to biological activity in their native solid state. Exposure to oxygen alone causes only a limited change in the redox state of HAs. Under the action of facultative anaerobes and aerobes, these substances undergo further chemical-physical and structural changes that are coherent with an enhanced capability to act as TEA. Although this was a laboratory experiment, it provided some mechanistic insights on the reasons of the variability observed in predicting the effects of the lowering of water table on GHG emissions from peatlands. Alteration of the hydrology of peat deposits caused by climate change might, per se, have only minor effects on the redox state of HA, but if coupled to intensified biological activity (caused, for instance, by vegetation changes which modify the availability of decomposable substrates) can result in an increase of oxidized redox active sites in HA. This may favor anaerobic respiration over fermentative processes, lowering $\mathrm{CH}_{4}$ emissions, but enhancing decomposition rates and the consequent larger release of $\mathrm{CO}_{2}$. Results of our laboratory study provide indications on factors that need to be confirmed in field studies. Kinetic factors of electron exchange could also, in fact, potentially impact microbial control on peat redox environment as electron transfer rates are, as shown by our results, significantly modified by exposure to biological activity in either aerobic or anaerobic conditions. Future research to predict GHG emission trends should therefore include monitoring of the redox status of HAs and of modifications in the availability of easily decomposable organic inputs in peatlands as key parameters affecting the variability of response to climate change.

Supplementary Materials: The following are available online at https:/ /www.mdpi.com/article/10 .3390/land10111189/s1, Figure S1: UV-vis spectra of HA; Figure S2: EEM fluorescence spectra of HA.

Author Contributions: Conceptualization, M.D.N. and R.T.; Methodology, C.B. and R.T.; Formal analysis, C.B.; Investigation, C.B. and M.C.; Data curation, C.B. and M.C.; Writing-original draft preparation, C.B.; Writing-review and editing, C.B., M.D.N., and M.C.; Supervision, M.D.N. and R.T. All authors have read and agreed to the published version of the manuscript.

Funding: This research received no external funding.

Data Availability Statement: All data used during the study appear in the submitted article.

Conflicts of Interest: The authors declare no conflict of interest.

List of Abbreviations: $\mathrm{ABTS}^{2-}=2,2^{\prime}$-Azinobis (3-ethylbenzothiazoline-6-sulfonic acid); ATR-FTIR = attenuated total reflectance Fourier-transform infrared; CV = cyclic voltammograms; $\mathrm{EDC}$ = electron donating capacity; $\mathrm{EEM}=$ excitation-emission matrix; $\mathrm{FI}=$ fluorescence intensity; $\mathrm{GC}=$ glassy carbon; $\mathrm{GHC}=$ greenhouse gases; $\mathrm{HA}=$ humic acids; $\mathrm{HA}_{0}=\mathrm{HA}$ extracted from the air-dried peat; $\mathrm{HA}_{\mathrm{ox}}=\mathrm{HA}$ extracted from the aerobically incubated peat; $\mathrm{HA}_{\text {red }}=\mathrm{HA}$ extracted from the anaerobically incubated peat; HSD = honestly significant difference; IHSS = International Humic Substances Society; $\mathrm{k}_{\mathrm{f}}$ = pseudo-first-order kinetic constant; $\mathrm{MEO}=$ mediated electrochemical oxidation; $\mathrm{N}_{\text {tot }}=$ total nitrogen; $\mathrm{OC}=$ organic carbon; $\mathrm{SA}=$ specific absorbance; $\mathrm{SHE}=$ standard hydrogen electrode; $\mathrm{SUVA}_{254}=$ specific UV absorbance at $254 \mathrm{~nm}$; TEA = terminal electron acceptors; $\mathrm{WE}=$ working electrode; $\mathrm{WHC}=$ water holding capacity.

\section{References}

1. Keiluweit, M.; Nico, P.S.; Kleber, M.; Fendorf, S. Are oxygen limitations under recognized regulators of organic carbon turnover in upland soils? Biogeochemistry 2016, 127, 157-171. [CrossRef]

2. Boye, K.; Noël, V.; Tfaily, M.; Bone, S.E.; Williams, K.H.; Bargar, J.R.; Fendorf, S. Thermodynamically controlled preservation of organic carbon in floodplains. Nat. Geosci. 2017, 10, 415-419. [CrossRef] 
3. Drake, H.L.; Horn, M.A.; Wüst, P.K. Intermediary ecosystem metabolism as a main driver of methanogenesis in acidic wetlands soil. Environ. Microbiol. Rep. 2009, 1, 307-318. [CrossRef] [PubMed]

4. Bridgham, S.D.; Cadillo-Quiroz, H.; Keller, J.K.; Zhuang, Q. Methane emissions from wetlands: Biogeochemical, microbial, and modeling perspectives from local to global scales. Glob. Chang. Biol. 2013, 19, 1325-1346. [CrossRef] [PubMed]

5. Davidson, E.A.; Janssens, I.A. Temperature sensitivity of soil carbon decomposition and feedbacks to climate change. Nature 2006, 440, 165-173. [CrossRef] [PubMed]

6. Ise, T.; Moorcroft, P.R. The global-scale temperature and moisture dependencies of soil organic carbon decomposition: An analysis using a mechanistic decomposition model. Biogeochemistry 2006, 80, 217-231. [CrossRef]

7. Guo, X.; Meng, M.; Zhang, J.; Chen, H.Y.H. Vegetation change impacts on soil organic carbon chemical composition in subtropical forests. Sci. Rep. 2016, 6, 29607. [CrossRef]

8. Keller, J.K.; Bridgham, S.D. Pathways of anaerobic carbon cycling across an ombrotrophic-minerotrophic peatland gradient. Limnol. Oceanogr. 2007, 52, 96-107. [CrossRef]

9. Ye, R.; Jin, Q.; Bohannan, B.; Keller, J.K.; Bridgham, S.D. Homoacetogenesis: A potentially underappreciated carbon pathway in peatlands. Soil Biol. Biochem. 2014, 68, 385-391. [CrossRef]

10. Mikaloff Fletcher, S.E.; Tans, P.P.; Bruhwiler, L.M.; Miller, J.B.; Heimann, M. CH4 sources estimated from atmospheric observations of $\mathrm{CH}_{4}$ and its ${ }^{13} \mathrm{C} /{ }^{12} \mathrm{C}$ isotopic ratios: 1. Inverse modeling of source processes. Glob. Biogeochem. Cycles. 2004, 18, GB4004. [CrossRef]

11. Keller, J.K.; Takagi, K.K. Solid-phase organic matter reduction regulates anaerobic decomposition in bog soil. Ecosphere 2013, 4, 1-10. [CrossRef]

12. Vile, M.A.; Bridgham, S.D.; Wieder, R.K. Response of anaerobic carbon mineralization rates to sulfate amendments in a boreal peatland. Ecol. Appl. 2003, 13, 720-734. [CrossRef]

13. Galand, P.E.; Yrjälä, K.; Conrad, R. Stable carbon isotope fractionation during methanogenesis in three boreal peatland ecosystems. Biogeosciences 2010, 7, 3893-3900. [CrossRef]

14. Lovley, D.R.; Coates, J.D.; Blunt-Harris, E.L.; Phillips, E.J.P.; Woodward, J.C. Humic substances as electron acceptors for microbial respiration. Nature 1996, 382, 445-448. [CrossRef]

15. Cervantes, F.J.; van der Velde, S.; Lettinga, G.; Field, J.A. Competition between methanogenesis and quinone respiration for ecologically important substrates in anaerobic consortia. FEMS Microbiol. Ecol. 2000, 34, 161-171. [CrossRef]

16. Keller, J.K.; Weisenhorn, P.B.; Megonigal, J.P. Humic acids as electron acceptors in wetland decomposition. Soil Biol. Biochem. 2009, 41, 1518-1522. [CrossRef]

17. Klüpfel, L.; Piepenbrock, A.; Kappler, A.; Sander, M. Humic substances as fully regenerable electron acceptors in recurrently anoxic environments. Nat. Geosci. 2014, 7, 195-200. [CrossRef]

18. Ye, R.; Keller, J.K.; Jin, Q.; Bohannan, B.J.M.; Bridgham, S.D. Peatland types influence the inhibitory effects of a humic substance analog on methane production. Geoderma 2016, 265, 131-140. [CrossRef]

19. Valenzuela, E.I.; Avendaño, K.A.; Balagurusamy, N.; Arriaga, S.; Nieto-Delgado, C.; Thalasso, F.; Cervantes, F.J. Electron shuttling mediated by humic substances fuels anaerobic methane oxidation and carbon burial in wetland sediments. Sci. Total Environ. 2019, 650, 2674-2684. [CrossRef] [PubMed]

20. Peiffer, S.; Kappler, A.; Haderlein, S.B.; Schmidt, C.; Byrne, J.M.; Kleindienst, S.; Vogt, C.; Richnow, H.H.; Obst, M.; Angenent, L.T.; et al. A biogeochemical-hydrological framework for the role of redox-active compounds in aquatic systems. Nat. Geosci. 2021, 14, 264-272. [CrossRef]

21. Leng, L.Y.; Ahmed, O.H.; Jalloh, M.B. Brief review on climate change and tropical peatlands. Geosci. Front. 2019, 10, 373-380. [CrossRef]

22. Morris, P.J. Wetter is better for peat carbon. Nat. Clim. Chang. 2021, 11, 561-562. [CrossRef]

23. Huang, Y.; Ciais, P.; Luo, Y.; Zhu, D.; Wang, Y.; Qiu, C.; Goll, D.S.; Guenet, B.; Makowski, D.; De Graaf, I.; et al. Tradeoff of CO2 and $\mathrm{CH} 4$ emissions from global peatlands under water-table drawdown. Nat. Clim. Chang. 2021, 11, 618-622. [CrossRef]

24. Hoyos-Santillan, J.; Lomax, B.H.; Large, D.; Turner, B.L.; Boom, A.; Lopez, O.R.; Sjögersten, S. Quality not quantity: Organic matter composition controls of $\mathrm{CO}_{2}$ and $\mathrm{CH}_{4}$ fluxes in neotropical peat profiles. Soil Biol. Biochem. 2016, 103, 86-96. [CrossRef]

25. Ise, T.; Dunn, A.L.; Wofsy, S.C.; Moorcroft, P.R. High sensitivity of peat decomposition to climate change through water-table feedback. Nat. Geosci. 2008, 1, 763-766. [CrossRef]

26. Gao, C.; Sander, M.; Agethen, S.; Knorr, K.H. Electron accepting capacity of dissolved and particulate organic matter control CO2 and $\mathrm{CH} 4$ formation in peat soils. Geochim. Cosmochim. Acta 2018, 245, 266-277. [CrossRef]

27. Roden, E.E.; Kappler, A.; Bauer, I.; Jiang, J.; Paul, A.; Stoesser, R.; Konishi, H.; Xu, H. Extracellular electron transfer through microbial reduction of solid-phase humic substances. Nat. Geosci 2010, 3, 417-421. [CrossRef]

28. Coles, J.R.P.; Yavitt, J.B. Linking belowground carbon allocation to anaerobic $\mathrm{CH} 4$ and $\mathrm{CO} 2$ production in a forested peatland, New York State. Geomicrobiol. J. 2004, 21, 445-455. [CrossRef]

29. Yavitt, J.B.; Williams, C.J. Linking tree species identity to anaerobic microbial activity in a forested wetland soil via leaf litter decomposition and leaf carbon fractions. Plant. Soil 2015, 390, 293-305. [CrossRef]

30. Barak, P.; Chen, Y. Equivalent radii of humic macromolecules from acid-base titration. Soil Sci. 1992, 152, 184-195. [CrossRef]

31. Inbar, Y.; Chen, Y.; Hadar, Y. Solid-state carbon-13 nuclear magnetic resonance and infrared spectroscopy of composted organic matter. Soil Sci. Soc. Am. J. 1989, 53, 1695-1701. [CrossRef] 
32. Bravo, C.; De Nobili, M.; Gambi, A.; Martin-Neto, L.; Nascimento, O.R.; Toniolo, R. Kinetics of electron transfer reactions by humic substances: Implications for their biogeochemical roles and determination of their electron donating capacity. Chemosphere 2022, 286, 131755. [CrossRef] [PubMed]

33. Aeschbacher, M.; Sander, M.; Schwarzenbach, R.P. Novel electrochemical approach to assess the redox properties of humic substances. Environ. Sci. Technol. 2010, 44, 87-93. [CrossRef] [PubMed]

34. Miller, J.C.; Miller, J.N. Statistics and Chemometrics for Analytical Chemistry, 6th ed.; Pearson: Harlow, UK, 2010.

35. R Development Core Team. R: A Language and Environment for Statistical Computing; R Foundation for Statistical Computing: Vienna, Austria, 2018.

36. Nicholson, R.S.; Shain, I. Theory of Stationary Electrode Polarography. Single Scan and Cyclic Methods Applied to Reversible, Irreversible, and Kinetic Systems. Anal. Chem. 1964, 36, 706-723. [CrossRef]

37. Chin, Y.P.; Aiken, G.; O'Loughlin, E. Molecular Weight, Polydispersity, and Spectroscopic Properties of Aquatic Humic Substances. Environ. Sci. Technol. 1994, 28, 1853-1858. [CrossRef]

38. Del Vecchio, R.; Blough, N.V. On the origin of the optical properties of humic substances. Environ. Sci. Technol. 2004, 38, 3885-3891. [CrossRef] [PubMed]

39. Chen, Y.; Senesi, N.; Schnitzer, M. Information provided on humic substances by E4/E6 ratios. Soil Sci. Soc. Am. J. 1977, 41, 352-358. [CrossRef]

40. Szajdak, L.; Szatylowicz, J. Impact of drainage on hydrophobicity of fen peat-moorsh soils. Mires Peat. 2010, 6, 158-174.

41. Aeschbacher, M.; Graf, C.; Schwarzenbach, R.P.; Sander, M. Antioxidant properties of Humic Substances. Environ. Sci. Technol. 2012, 46, 4916-4925. [CrossRef]

42. Nurmi, J.T.; Tratnyek, P.G. Electrochemical properties of natural organic matter (NOM), fractions of NOM, and model biogeochemical electron shuttles. Environ. Sci. Technol. 2002, 36, 617-624. [CrossRef]

43. Maurer, F.; Christl, I.; Kretzschmar, R. Reduction and reoxidation of humic acid: Influence on spectroscopic properties and proton binding. Environ. Sci. Technol. 2010, 44, 5787-5792. [CrossRef] [PubMed]

44. Boyle, E.S.; Guerriero, N.; Thiallet, A.; Del Vecchio, R.; Blough, N.V. Optical properties of humic substances and CDOM: Relation to structure. Environ. Sci. Technol. 2009, 43, 2262-2268. [CrossRef] [PubMed]

45. Macalady, D.; Walton-Day, K. New light on a dark subject: On the use of fluorescence data to deduce redox states of natural organic matter (NOM). Aquat. Sci. 2009, 71, 135-143. [CrossRef]

46. Zaccone, C.; Cocozza, C.; D'Orazio, V.; Plaza, C.; Cheburkin, A.; Miano, T.M. Influence of extractant on quality and trace elements content of peat humic acids. Talanta 2007, 73, 820-830. [CrossRef] [PubMed]

47. Zykova, M.V.; Schepetkin, I.A.; Belousov, M.V.; Krivoshchekov, S.V.; Logvinova, L.A.; Bratishko, K.A.; Yusubov, M.S.; Romanenko, S.V.; Quinn, M.T. Physicochemical Characterization and Antioxidant Activity of Humic Acids Isolated from Peat of Various Origins. Molecules 2018, 23, 753. [CrossRef] 